\title{
Maturation of Calcium Transport in Cardiac Sarcoplasmic Reticulum
}

\author{
LYNN MAHONY
}

Department of Pediatrics, University of Texas Southwestern Medical Center at Dallas, Dallas, Texas 75235

\begin{abstract}
Developmental changes in myocardial function have been described by a number of investigators. To further define the cellular basis for these changes, the present study was designed to characterize age-related changes in $\mathrm{Ca}^{2+}$ transport in sarcoplasmic reticulum (SR) vesicles isolated from six groups of sheep: group (Sp) I (100-105 days gestation), Gp II (128-132 days gestation), Gp III (postnatal, 0-3 days), Gp IV (4 wk), Gp V (8 wk), and Gp VI (maternal sheep). The maximal $\mathrm{Ca}^{2+}$ uptake for vesicles isolated from Gp I-V was significantly $(p<$ 0.01) decreased as compared to that measured for Gp VI (maternal) vesicles. However, $\mathrm{Ca}^{2+}$-dependent ATP hydrolysis was decreased only in the fetal SR vesicles (Gp III). Thus, decreased ATP hydrolysis only partially explained the decreased $\mathrm{Ca}^{2+}$ uptake. In contrast, calculation of apparent $\mathrm{Ca}^{2+}$ pump coupling ratios (mol of $\mathrm{Ca}^{2+}$ transported/mol of ATP hydrolyzed) showed that there was a marked increase in the coupling of $\mathrm{Ca}^{2+}$ transport to ATP hydrolysis during maturation of the heart. Inasmuch as the contractile state of the heart depends on precise regulation of $\mathrm{Ca}^{2+}$ concentration by the $\mathrm{SR}$, these age-related changes in SR function may contribute to developmental changes in myocardial function. (Pediatr Res 24: 639-643, 1988)
\end{abstract}

\section{Abbreviations}

SR, sarcoplasmic reticulum

Gp, group

In sheep, the immature heart functions in vivo at a higher resting level of myocardial function; however, the intrinsic contractility of the immature myocardium appears diminished and may not reach adult levels until 4 to $8 \mathrm{wk}$ of postnatal life (1-7). Although the cellular basis of these developmental changes in myocardial function is not known, age-related changes in SR function may play a role because this organelle participates in regulation of intracellular $\mathrm{Ca}^{2+}$ concentration, an important determinant of contractility. Release of $\mathrm{Ca}^{2+}$ from the cardiac SR is largely responsible for initiation of muscle contraction and $\mathrm{Ca}^{2+}$ uptake by the SR results in muscle relaxation (8).

Previously, we have observed that cardiac SR vesicles isolated from fetal sheep (gestational age of 128-132 days, term is 145 days) showed decreased ability to accumulate $\mathrm{Ca}^{2+}$ and decreased $\mathrm{Ca}^{2+}$-dependent ATP hydrolysis as compared to $\mathrm{SR}$ vesicles isolated from maternal sheep (9). We concluded that developmental changes in myocardial function may be due, in part, to

Received April 6, 1988; accepted July 25, 1988.

Lynn Mahony, M.D., University of Texas Southwestern Medical Center, Department of Pediatrics, 5323 Harry Hines Boulevard, Dallas, TX 75235.

Supported by Grant HLO 1794 from the National Institutes of Health and a Basil O'Connor Research Scholar Award from the March of Dimes Birth Defects Foundation. alterations in $\mathrm{Ca}^{2+}$ transport by SR during development. The present study was designed to further characterize age-related changes in cardiac SR by measuring $\mathrm{Ca}^{2+}$ transport in $\mathrm{SR}$ vesicles isolated from fetal, postnatal, and adult sheep.

\section{MATERIALS AND METHODS}

Experimental animals. Cardiac membrane vesicles enriched in SR were isolated from six groups of sheep: Gp I (fetus, 100105 days gestation), Gp II (fetus, 128-132 days gestation), Gp III (newborn, 0-3 days), Gp IV (postnatal, 4 wk), Gp V (postnatal, $8 \mathrm{wk}$ ), and Gp VI (maternal sheep). No differences in $\mathrm{Ca}^{2+}$ transport were detected between cardiac SR vesicles isolated from pregnant and nonpregnant sheep (data not shown). The sheep were anesthetized with methohexibarbital, and the hearts quickly excised and placed in ice-cold isotonic saline. To obtain an adequate amount of myocardial tissue, both ventricles were trimmed free of endocardium, epicardium, and large coronary arteries and then used for vesicle preparations for Gp I, II, and III. A portion of the left ventricle and septum was used for $\mathrm{Gp}$ IV, V, and VI. We have reported previously no difference in $\mathrm{Ca}^{2+}$ transport between vesicles isolated from the right and left ventricles of fetal or maternal sheep (9). The weight of the ventricles used averaged $10.6 \pm 1.7 \mathrm{~g}, 16.0 \pm 2.0 \mathrm{~g}, 23.9 \pm 1.2 \mathrm{~g}$, $25.7 \pm 4.7 \mathrm{~g}, 28 \pm 0 \mathrm{~g}$, and $27.3 \pm 2.0 \mathrm{~g}$ for sheep in Gp I, II, III, IV, V, and VI, respectively (mean \pm SD). The results for Gp II and VI have been reported previously (9) and are included here for purposes of comparison.

Isolation of cardiac $S R$ vesicles. Cardiac SR vesicles were isolated as described previously (9). All procedures were performed at $4^{\circ} \mathrm{C}$. A total of 4 to $6 \mathrm{~g}$ of trimmed ventricular tissue was homogenized two to three times for $30 \mathrm{~s}$ in $4 \mathrm{vol}$ of $10 \mathrm{mM}$ $\mathrm{NaHCO}_{3}$ with a Polytron PT-10-35 (Brinkmann Instruments Co., Westbury, CT) set at 50 to $75 \%$ of maximum speed. In general, we found that the more immature hearts required less homogenization to obtain optimal $\mathrm{Ca}^{2+}$ uptake. The initial homogenate was spun twice at $14,000 \times g_{\max }$ for $20 \mathrm{~min}$, and then the supernatant from the second centrifugation was sedimented at $45,000 \times g_{\max }$ for $30 \mathrm{~min}$ to yield membrane vesicles enriched in SR. The vesicles were washed with $0.6 \mathrm{M} \mathrm{KCl}, 30 \mathrm{mM}$ histidine ( $\mathrm{pH} 7.0)$, and stored frozen at $-20^{\circ} \mathrm{C}$. Protein concentrations were determined by the method of Lowry et al. (10).

Assay of ATPase activities. Total ATPase activities of SR vesicles were measured at $37^{\circ} \mathrm{C}$ in buffer containing $50 \mathrm{mM}$ histidine, $3 \mathrm{mM} \mathrm{MgCl}, 100 \mathrm{mM} \mathrm{KCl}, 50 \mu \mathrm{M} \mathrm{CaCl}_{2}, 3 \mu \mathrm{g} / \mathrm{ml}$ A23187, and $3 \mathrm{mM} \mathrm{Na}{ }_{2} \mathrm{ATP}$ (pH 7.4) (11). Basal ATPase activity was measured in the presence of $1 \mathrm{mM}$ EGTA. Production of inorganic phosphate from ATP was measured colorimetrically (11). $\mathrm{Ca}^{2+}$-dependent ATPase activity was obtained by subtracting the basal activity from the total ATPase activity.

Azide-sensitive ATPase activity is a marker for mitochondrial membranes and was measured to assess mitochondrial contamination in the SR preparations. Azide-sensitive ATPase activity was determined by subtracting the ATPase activity measured in 
the presence of $5 \mathrm{mM}$ sodium azide from the total ATPase activity (11).

$\mathrm{Na}^{+}, \mathrm{K}^{+}$-ATPase activity was measured to assess sarcolemmal contamination in the SR preparations (12). The assay was performed at $37^{\circ} \mathrm{C}$ in buffer containing $50 \mathrm{mM}$ histidine, $3 \mathrm{mM}$ $\mathrm{MgCl}_{2}, 100 \mathrm{mM} \mathrm{NaCl}, 10 \mathrm{mM} \mathrm{KCl}$, and $3 \mathrm{mM} \mathrm{Na}{ }_{2} \mathrm{ATP}(\mathrm{pH}$ 6.8). $\mathrm{Na}^{+}, \mathrm{K}^{+}$-ATPase activity was that activity inhibited by 1 $\mathrm{mM}$ ouabain. Before the assay, membrane vesicles were treated with sodium dodecyl sulfate so that $\mathrm{Na}^{+}, \mathrm{K}^{+}$-ATPase activity was measured in both right-side-out and inside-out vesicles (12).

Assay of $\mathrm{Ca}^{2+}$ Uptake. $\mathrm{Ca}^{2+}$ uptake by SR vesicles was measured at $37^{\circ} \mathrm{C}$ in buffer containing $50 \mathrm{mM}$ histidine, $3 \mathrm{mM}$ $\mathrm{MgCl}_{2}, 100 \mathrm{mM} \mathrm{KCl}, 5 \mathrm{mM}$ sodium azide, $3 \mathrm{mM}$ Tris oxalate, $50 \mu \mathrm{M}^{45} \mathrm{CaCl}_{2}, 0.010-0.020 \mathrm{mg}$ of membrane protein, and 3 $\mathrm{mM} \mathrm{Na} \mathrm{A}_{2} \mathrm{ATP}$ (pH 6.8) (11). This slightly acidic $\mathrm{pH}$ was chosen to optimize ATP-dependent $\mathrm{Ca}^{2+}$ uptake (13). The vesicles were preincubated for $10 \mathrm{~min}$ in buffer at $37^{\circ} \mathrm{C}$ and the reactions were started by addition of ATP. Active transport of ${ }^{45} \mathrm{Ca}^{2+}$ inside the vesicles was measured by liquid scintillation counting after collection of the vesicles on Whatman GF/C filters (Whatman Inc., Clifton, $\mathrm{NJ}$ ) by rapid filtration (11). Addition of the $\mathrm{Ca}^{2+}$ ionophore, A23187, to the incubation buffer inhibited more than $99 \%$ of the $\mathrm{Ca}^{2+}$ uptake, verifying that $\mathrm{Ca}^{2+}$ was specifically transported inside the vesicles (data not shown).

The activity of the $\mathrm{Ca}^{2+}$-dependent ATPase enzyme $\left(\mathrm{Ca}^{2+}\right.$ pump) serves two functions: energy transduction (ATP hydrolysis) and $\mathrm{Ca}^{2+}$ translocation $\left(\mathrm{Ca}^{2+}\right.$ uptake). Inasmuch as observed age-related changes in $\mathrm{Ca}^{2+}$ uptake could result from age-related alterations in the efficiency of coupling of ATP hydrolysis to $\mathrm{Ca}^{2+}$ transport, we calculated apparent $\mathrm{Ca}^{2+}$ pump coupling ratios (mol of $\mathrm{Ca}^{2+}$ transported/mol of ATP hydrolyzed). This was done by measuring $\mathrm{Ca}^{2+}$ uptake and $\mathrm{Ca}^{2+}$-dependent ATPase activities simultaneously by taking aliquots from the same suspension of vesicles to determine the amount of ${ }^{45} \mathrm{Ca}^{2+}$ retained by the vesicles and the ATPase activity at a time when $\mathrm{Ca}^{2+}$ uptake was linear with time ( $2 \mathrm{~min}$ after the reaction was started). The apparent $\mathrm{Ca}^{2+}$ pump coupling ratio was obtained by dividing the $\mathrm{Ca}^{2+}$ uptake by the $\mathrm{Ca}^{2+}$-dependent ATPase activity.

Formation of acylphosphoprotein intermediate of the $\mathrm{Ca}^{2+}$ pump with $\left[\gamma^{32} P\right]$ ATP. To obtain an estimate of actual $\mathrm{Ca}^{2+}$ pump density in the membrane preparations, acylphosphoprotein (phosphorylated intermediate) levels of $\mathrm{Ca}^{2+}$ pumps were measured. During $\mathrm{Ca}^{2+}$-dependent ATP hydrolysis, the terminal phosphate is incorporated into the ATPase $\left(\mathrm{Ca}^{2+}\right.$ pump) protein. The amount of acylphosphoprotein formed, therefore, is directly related to the actual number of $\mathrm{Ca}^{2+}$ pumps. $\mathrm{Ca}^{2+}$-dependent phosphorylations were performed in the presence of $\left[\gamma^{32} \mathrm{P}\right]$ ATP as described previously (9). Membrane protein was phosphorylated and then subjected to gel electrophoresis (14). After electrophoresis, the radioactivity in the ${ }^{32} \mathrm{P}$-labeled, $100,000 \mathrm{Da} \mathrm{Ca}^{2+}$ pump monomers was quantitated by liquid scintillation counting. The specific incorporation of radioactivity into $\mathrm{Ca}^{2+}$-dependent ATPase was defined as that incorporation inhibited by $1 \mathrm{mM}$ EGTA when $\mathrm{Ca}^{2+}$ was not included in the reaction buffer. $\left[\gamma^{32} \mathrm{P}\right]$ phosphoprotein with this gel electrophoresis method (9).
All results were corrected for the measured $15 \%$ recovery of acyl To determine the impact of age-related changes in turnover of the ATPase enzyme on developmental changes in SR $\mathrm{Ca}^{2+}$ transport, apparent turnover numbers $\left(\mathrm{min}^{-1}\right)$ or cycling times for $\mathrm{Ca}^{2+}$ pumps $\left(37^{\circ} \mathrm{C}\right)$ were calculated. Essentially, the turnover number normalizes the activity of the ATPase enzyme (ATP hydrolysis) to the density of $\mathrm{Ca}^{2+}$ pumps. Turnover numbers were calculated by dividing the maximal $\mathrm{Ca}^{2+}$-dependent ATPase activities measured at $37^{\circ} \mathrm{C}$ by the maximal acylphosphoprotein levels formed at $4^{\circ} \mathrm{C}(15)$.

Statistical analysis. Comparisons between the data from vesicles isolated from different age groups were performed by oneway analysis of variance or by Welch's approximation to the one-way analysis of variance for groups with unequal variances. The Newman-Keuls test for multiple comparisons also was performed (16). A significant difference was considered to exist when $p<0.05$. All data are expressed as mean $\pm \mathrm{SD}$.

Materials. $\left[\gamma{ }^{32} \mathrm{P}\right]$ ATP $(3000 \mathrm{Ci} / \mathrm{mmol})$ and ${ }^{45} \mathrm{CaCl}_{2}(4-30$ $\left.\mathrm{Ci} / \mathrm{g} \mathrm{Ca}^{2+}\right)$ were obtained from New England Nuclear, Boston, MA. All other chemicals were purchased from Sigma Chemical Co., St. Louis, MO.

\section{RESULTS}

Yield and purity of SR vesicles. The yield of cardiac SR vesicles from immature myocardium was somewhat decreased as compared to that from more mature myocardium (Table 1). These data were consistent with ultrastructural studies showing a greater ratio of contractile to noncontractile elements in mature myocardium $(17,18)$. Specific activities of $\mathrm{Na}^{+}, \mathrm{K}^{+}$-ATPase, a sarcolemmal marker, were statistically higher in $\mathrm{Gp}$ I vesicles but this was of doubtful significance (Table 1). All activities measured in the SR preparations were considerably lower $(<1 / 3)$ than the activities previously measured in sarcolemmal preparations isolated from fetal (Gp II) $(68.7 \pm 3.0 \mu \mathrm{mol} \mathrm{Pi} / \mathrm{mg}$ protein $\cdot \mathrm{h}, n=$ $3)$ and maternal $(114.0 \pm 3.1 \mu \mathrm{mol} \mathrm{Pi} / \mathrm{mg}$ protein $\cdot \mathrm{h}, n=3)$ sheep hearts (9). Azide-sensitive ATPase activities, a mitochondrial marker, were similar and also relatively low in all SR preparations (Table 1). Although azide-sensitive ATPase activities were not measured in mitochondria isolated from fetal and maternal sheep hearts, we have previously demonstrated that mitochondrial contamination was $<2 \%$ as assessed by assay of cytochrome $c$ oxidase activities in SR vesicles and in mitochondria from fetal (Gp II) and maternal hearts (9).

$\mathrm{Ca}^{2+}$ uptake and $\mathrm{Ca}^{2+}$-dependent ATPase activities of $S R$ vesicles. SR vesicles isolated from hearts of all age groups showed active transport of $\mathrm{Ca}^{2+}$. $\mathrm{Ca}^{2+}$ uptake was linear with respect to time during the first 2 to $3 \mathrm{~min}$ of the reaction and then reached a plateau after 7 to 9 min (Fig. 1). There was a striking increase in both the rate and extent of $\mathrm{Ca}^{2+}$ uptake/mg of protein during development. The initial $\mathrm{Ca}^{2+}$ uptake velocities (measured over the first 2 min of the reaction) and the maximal $\mathrm{Ca}^{2+}$ uptakes for vesicles isolated from Gp I-V (fetal and postnatal) were all significantly $(p<0.01)$ decreased as compared to that measured for $\mathrm{Gp}$ VI (maternal) vesicles.

Table 1. Yield and purity of $S R$ vesicles (mean $\pm S D)^{*}$

\begin{tabular}{|c|c|c|c|c|}
\hline Group & $n$ & $\begin{array}{c}\text { Yield } \\
(\mathrm{mg} / \mathrm{g})\end{array}$ & $\begin{array}{c}\mathrm{Na}^{+}, \mathrm{K}^{+}- \\
\text {ATPase }(\mu \mathrm{mol} \mathrm{Pi} / \mathrm{mg} \cdot \mathrm{h})\end{array}$ & $\begin{array}{c}\text { Azide-sensitive } \\
\text { ATPase }(\mu \mathrm{mol} \\
\mathrm{Pi} / \mathrm{mg} \cdot \mathrm{h})\end{array}$ \\
\hline I (fetal, 100-105 days) & 6 & $0.45 \pm 0.07 \dagger$ & $22.2 \pm 5.1 \dagger$ & $7.0 \pm 1.5$ \\
\hline II (fetal, $128-132$ days) & 6 & $0.42 \pm 0.09 \uparrow$ & $19.1 \pm 4.5$ & $6.0 \pm 1.5$ \\
\hline III (newborn, 0-3 days) & 3 & $0.54 \pm 0.17$ & $14.0 \pm 10.7$ & $9.7 \pm 4.3$ \\
\hline IV (postnatal, $4 \mathrm{wk}$ ) & 4 & $0.39 \pm 0.06 \dagger$ & $22.2 \pm 3.3$ & $7.2 \pm 2.3$ \\
\hline $\mathrm{V}$ (postnatal, $8 \mathrm{wk})$ & 8 & $0.54 \pm 0.02$ & $18.9 \pm 4.0$ & $7.3 \pm 2.1$ \\
\hline VI (maternal) & 6 & $0.62 \pm 0.14$ & $13.0 \pm 2.8$ & $8.4 \pm 2.6$ \\
\hline
\end{tabular}

\footnotetext{
* Yield measured in mg protein/g ventricle (wet weight).

$\dagger$ Significantly different than value for Gp VI, $p<0.05$.
} 
The simplest explanation for the decreased $\mathrm{Ca}^{2+}$ uptake observed in SR vesicles from immature hearts was that these membranes contained fewer $\mathrm{Ca}^{2+}$ pumps. Therefore, one might expect that $\mathrm{Ca}^{2+}$-dependent ATP hydrolysis would be significantly decreased in the SR preparations from immature hearts. However, $\mathrm{Ca}^{2+}$-dependent ATPase activities were not different in vesicles from Gp III-VI (newborn, postnatal, and maternal) (Table 2). Only in vesicles from fetal lambs (Gp I and II) were the $\mathrm{Ca}^{2+}$-dependent ATPase activities significantly lower $(p<$ 0.05). Thus, decreased rate of ATP hydrolysis only partially explained the lower rates of $\mathrm{Ca}^{2+}$ uptake in vesicles from immature hearts. Simultaneous measurement of $\mathrm{Ca}^{2+}$ uptake rates and $\mathrm{Ca}^{2+}$-dependent ATPase activities confirmed that the $\mathrm{Ca}^{2+}$ uptake rates measured for Gp I-V vesicles were disproportionately lower than the ATP hydrolysis rates (Fig. 2). The apparent $\mathrm{Ca}^{2+}$ pump coupling ratio (mol of $\mathrm{Ca}^{2+}$ transported/mol of ATP hydrolyzed) for vesicles from Gp I was only $15 \%$ of the ratio measured for $\mathrm{Gp}$ VI (maternal) vesicles $(p<0.01)$. The coupling ratio gradually increased in $\mathrm{SR}$ vesicles isolated from more mature hearts but even at $8 \mathrm{wk}$ of age $(\mathrm{Gp} \mathrm{V})$, the ratio was only $75 \%$ of the maternal value $(p<0.01)$.

$\mathrm{Ca}^{2+}$ pump densities in $\mathrm{SR}$ vesicles. The fact that $\mathrm{Ca}^{2+}-\mathrm{de}-$ pendent ATPase activities for SR vesicles from fetal hearts (Gp I and II) were decreased was suggestive that these membranes contained fewer $\mathrm{Ca}^{2+}$ pumps than membranes isolated from

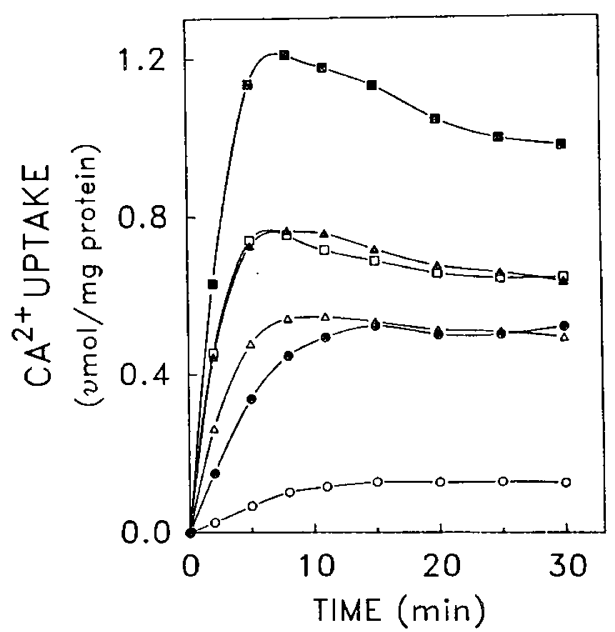

Fig. 1. Time course for $\mathrm{Ca}^{2+}$ uptake by cardiac $\mathrm{SR}$ vesicles. Cardiac $\mathrm{SR}$ vesicles were isolated from Gp I (open circles), Gp II (closed circles), Gp III (open triangles), Gp IV (closed triangles), Gp V (open squares), and $\mathrm{Gp}$ VI (closed squares) sheep. $\mathrm{Ca}^{2+}$ uptake was measured at $37^{\circ} \mathrm{C}$ in buffer containing $50 \mathrm{mM}$ histidine, $3 \mathrm{mM} \mathrm{MgCl}_{2}, 100 \mathrm{mM} \mathrm{KCl}, 3$ $\mathrm{mM}$ Tris oxalate, $50 \mu \mathrm{m}{ }^{45} \mathrm{CaCl}_{2}, 0.020 \mathrm{mg} / \mathrm{ml}$ membrane protein, and $3 \mathrm{mM} \mathrm{Na}_{2}$ ATP as described in "Materials and methods." Values are the mean of three to eight experiments ( $\mathrm{SD}=20-90 \%$ of value). The initial velocity of $\mathrm{Ca}^{2+}$ uptake and maximal $\mathrm{Ca}^{2+}$ uptake measured in vesicles from Gp I-V was significantly $(p<0.01)$ less than that measured in Gp VI vesicles. more mature hearts. To confirm that $\mathrm{Ca}^{2+}$ pump densities were indeed decreased in fetal SR vesicles, the $\mathrm{Ca}^{2+}$ pumps were quantitated directly by formation of their acylphosphoprotein intermediates (Table 2). Similar to the results obtained for $\mathrm{Ca}^{2+}$ dependent ATPase activities, the acylphosphoprotein concentrations measured for vesicles from Gp I and II (fetal hearts) were decreased significantly compared to the values measured for $\mathrm{Gp}$ VI (maternal) vesicles. From these data, the apparent turnover numbers or cycling times for $\mathrm{Ca}^{2+}$ pumps $\left(\mathrm{Ca}^{2+}\right.$-dependent ATPase activity/acylphosphoprotein concentration) were calculated (Fig. 3). The turnover numbers were higher for vesicles from $\mathrm{Gp}$ I and II than that measured for Gp VI vesicles but this was significant $(p<0.05)$ only for $\mathrm{Gp}$ II vesicles. Turnover numbers for SR vesicles from newborn and other postnatal lambs were not different than that obtained for the SR vesicles from maternal sheep.

\section{DISCUSSION}

Methodologic considerations. When studying the function of cardiac SR vesicles isolated from different age groups of sheep; the possibility of differential contamination of the SR preparations must be considered. It could be argued that indices of SR function such as $\mathrm{Ca}^{2+}$-dependent ATP hydrolysis $\left(\mu \mathrm{mol}\right.$ of $\mathrm{Ca}^{2+} /$ $\mathrm{mg}$ protein $\cdot \mathrm{hr}$ ) and $\mathrm{Ca}^{2+}$ uptake ( $\mu \mathrm{mol}$ of $\mathrm{Ca}^{2+} / \mathrm{mg}$ protein) may be decreased in vesicles from immature hearts because of varying amounts of other membrane contaminants or because of varying amounts of other SR proteins. For example, although the activities of the marker enzymes for mitochondrial and sarcolemmal membranes were low in all SR preparations, the data in Table 1 are suggestive that the SR preparations from the

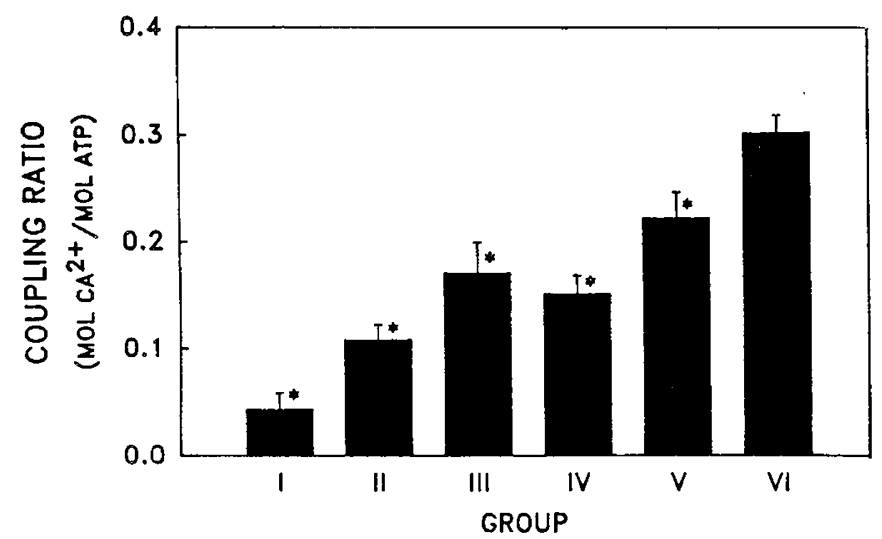

Fig. 2. Apparent $\mathrm{Ca}^{2+}$ pump coupling ratio in $\mathrm{SR}$ vesicles. $\mathrm{Ca}^{2+}$ uptake and $\mathrm{Ca}^{2+}$-dependent ATPase activities were measured simultaneously at $37^{\circ} \mathrm{C}$ as described in "Materials and methods." The coupling ratio is that between the uptake rate and the $\mathrm{Ca}^{2+}$ dependent ATPase activity. ${ }^{*}$ Significantly less than the value for Gp VI vesicles, $p<0.01$. Values are mean \pm SD.

Table 2. $\mathrm{Ca}^{2+}$ ATPase activities and acyl phosphoprotein levels in $S R$ vesicles (mean $\pm S D$ )

\begin{tabular}{cccc}
\hline Group & n & $\begin{array}{c}\mathrm{Ca}^{2+} \text { ATPase } \\
\text { Activity } \\
(\mu \mathrm{mol} \mathrm{Pi} \\
\mathrm{mg} \cdot \mathrm{h})\end{array}$ & $\begin{array}{c}\text { Acylphosphoprotein } \\
(\mathrm{pmol} \mathrm{Pi} / \mathrm{mg})\end{array}$ \\
\hline I (fetal, 100-105 days) & 6 & $18.8 \pm 5.1^{*}$ & $122 \pm 29^{*}$ \\
II (fetal, 128-132 days) & 6 & $36.7 \pm 6.5^{*}$ & $195 \pm 44^{*}$ \\
III (newborn, 0-3 days) & 3 & $48.1 \pm 5.2$ & $322 \pm 61$ \\
IV (postnatal, 4 wk) & 4 & $90.4 \pm 31.4$ & $730 \pm 300$ \\
V (postnatal, 8 wk) & 4 & $55.6 \pm 8.6$ & $498 \pm 67$ \\
VI (maternal) & 6 & $55.7 \pm 6.0$ & $497 \pm 126$ \\
\hline
\end{tabular}

\footnotetext{
* Significantly less than value for SR vesicles in Gp VI, $p<0.05$.
} 


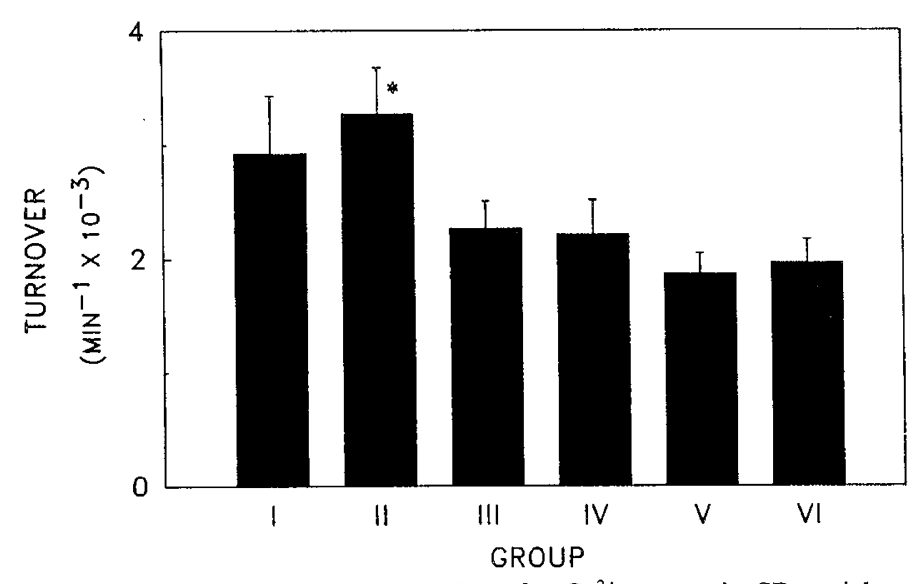

Fig. 3. Apparent turnover numbers for $\mathrm{Ca}^{2+}$ pumps in $\mathrm{SR}$ vesicles. $\mathrm{Ca}^{2+}$-dependent ATPase activities were measured at $37^{\circ} \mathrm{C}$ and maximal acylphosphoprotein levels were measured at $4^{\circ} \mathrm{C}$ as described in "Materials and methods." The turnover number represents the ratio between the $\mathrm{Ca}^{2+}$-dependent ATPase activity and acylphosphoprotein level. * Significantly less than the value obtained for Gp VI vesicles, $p<0.05$.

fetal hearts contained more mitochondrial and sarcolemmal membranes relative to SR membranes than did the SR preparations from maternal hearts. For this reason, it was important to examine indices of SR $\mathrm{Ca}^{2+}$ transport that were independent of the composition of the individual SR preparations. The apparent coupling ratios for $\mathrm{Ca}^{2+}$ transport $\left(\mathrm{mol} \mathrm{Ca} \mathrm{Ca}^{2+} / \mathrm{mol} \mathrm{ATP}\right)$ were decreased whereas apparent $\mathrm{Ca}^{2+}$ pump turnover numbers $\left(\mathrm{min}^{-1}\right)$ were increased in SR vesicles isolated from immature hearts (Figs. 2 and 3). It is difficult to explain these differences on the basis of varying degrees of purity among the SR preparations. In addition, we have shown previously that $\mathrm{Ca}^{2+}$ uptake measured in crude myocardial homogenates of Gp II (fetal) hearts was decreased as compared to that measured in homogenates of Gp VI (maternal) hearts (9). Thus, it is likely that the preparations of SR vesicles described in this report reflect the SR content of the entire heart and that differences in relative amounts of SR recovered in the various preparations do not account for differences in measured rates of $\mathrm{Ca}^{2+}$ transport.

Mechanism of decreased $\mathrm{Ca}^{2+}$ uptake. The SR is an enclosed membrane compartment within the myocardial cell. It is a relatively simple membrane containing $\mathrm{Ca}^{2+}$ pumps, $\mathrm{Ca}^{2+}$ release channels, and several regulatory proteins. When the myocardium is homogenized, the SR membrane is first fragmented but then forms into sealed vesicles that can be separated from other cell constituents by centrifugation. The SR vesicles, which contain both $\mathrm{Ca}^{2+}$ pumps and $\mathrm{Ca}^{2+}$ release channels, retain the ability to pump $\mathrm{Ca}^{2+}$ and thus, $\mathrm{Ca}^{2+}$ transport can be studied in vitro.

The measured amount of $\mathrm{Ca}^{2+}$ transported into the $\mathrm{SR}$ vesicles depends on several factors. First, is the amount of ATP hydrolysis by the $\mathrm{Ca}^{2+}$ pump or ATPase enzyme. This, in turn, depends on the density of $\mathrm{Ca}^{2+}$ pumps and on the turnover or cycling time of the ATPase enzyme. Second, the measured $\mathrm{Ca}^{2+}$ uptake depends on the coupling of $\mathrm{Ca}^{2+}$ transport to ATP hydrolysis. Finally, because the SR vesicles contain both $\mathrm{Ca}^{2+}$ pumps and $\mathrm{Ca}^{2+}$ release channels, the measured $\mathrm{Ca}^{2+}$ uptake is actually the net balance between $\mathrm{Ca}^{2+}$ influx and $\mathrm{Ca}^{2+}$ efflux. Thus, measured $\mathrm{Ca}^{2+}$ uptake depends also on the $\mathrm{Ca}^{2+}$ efflux.

The results of the present study demonstrate that $\mathrm{Ca}^{2+}$ uptake is decreased in SR vesicles from immature hearts. These results are similar to those reported by other investigators $(19,20)$. It has been suggested that the decreased $\mathrm{Ca}^{2+}$ transport of SR vesicles from fetal hearts might be explained by the smaller size of the vesicles (19). However, at least for the SR preparations described in this report, vesicle size probably did not limit $\mathrm{Ca}^{2+}$ uptake, because $\mathrm{Ca}^{2+}$ uptake could be augmented in all prepa- rations by altering experimental conditions. For example, incubation with ryanodine, a plant alkaloid that purportedly blocks $\mathrm{Ca}^{2+}$ efflux from SR vesicles $(21,22)$ increased $\mathrm{Ca}^{2+}$ uptake by 50 to $100 \%$ in all preparations (data not shown).

Certainly some portion of the decreased $\mathrm{Ca}^{2+}$ uptake observed in SR vesicles isolated from fetal (Gp I and II) hearts can be explained by decreased $\mathrm{Ca}^{2+}$-dependent ATP hydrolysis. This decreased $\mathrm{Ca}^{2+}$-dependent ATP hydrolysis is suggestive that the density of $\mathrm{Ca}^{2+}$ pumps might be decreased in SR vesicles isolated from fetal hearts. This conclusion was verified by the finding that acylphosphoprotein intermediates of the $\mathrm{Ca}^{2+}$ pump were decreased in vesicles from fetal hearts. Somewhat surprising, however, was the observation that the apparent turnover numbers for the ATPase enzyme were actually higher in SR vesicles from fetal hearts. The reason for this is not clear but the higher apparent turnover of the $\mathrm{Ca}^{2+}$ pump enzyme may compensate in part for the decreased pump density in the fetal myocardium. Decreased density of $\mathrm{Ca}^{2+}$ pumps cannot account for the observation that $\mathrm{Ca}^{2+}$ uptake measured in SR vesicles from $\mathrm{Gp}$ III, IV, and V (newborn and postnatal) was significantly lower than that measured in maternal vesicles. In fact, $\mathrm{Ca}^{2+}$-dependent ATP hydrolysis in vesicles from postnatal sheep in Gp IV and V was greater than or equal to that measured in vesicles from maternal hearts. Measurement of apparent $\mathrm{Ca}^{2+}$ pump coupling ratios (mol of $\mathrm{Ca}^{2+}$ transported/mol of ATP hydrolyzed) showed that there was a dramatic increase in the apparent coupling of $\mathrm{Ca}^{2+}$ transport to ATP hydrolysis during maturation of the heart. Thus, the SR membrane in the immature heart pumps $\mathrm{Ca}^{2+}$ relatively inefficiently.

Inasmuch as measured $\mathrm{Ca}^{2+}$ uptake is the sum of $\mathrm{Ca}^{2+}$ influx and $\mathrm{Ca}^{2+}$ efflux, another possible explanation for the decreased $\mathrm{Ca}^{2+}$ uptake (and decreased coupling ratios) measured in SR vesicles from immature hearts is that there may be differences in $\mathrm{Ca}^{2+}$ release and/or storage between $\mathrm{SR}$ vesicles isolated from immature and mature hearts. The data presented here are consistent with the conclusion that vesicles from immature hearts may have increased $\mathrm{Ca}^{2+}$ efflux or a decreased ability to store accumulated $\mathrm{Ca}^{2+}$.

Implications of current work. Although the contractile state of the heart depends on many factors, it is generally accepted that the rate and extent of $\mathrm{Ca}^{2+}$ uptake by the SR influence two important aspects of myocardial performance: the rate of diastolic relaxation and force of systolic contraction $(8,23)$. Inasmuch as the rate and maximal extent of $\mathrm{Ca}^{2+}$ uptake were decreased in SR vesicles from immature hearts, we would expect the rate of relaxation to be decreased in the immature heart as compared to the adult. This expectation is supported by physiologic observations. For example, one of the major effects of $\beta$ adrenergic stimulation is to increase the rate of myocardial relaxation (8). Indeed, the decrease in half-time to relaxation in perfused 21-day fetal rabbit hearts in response to isoproterenol was significantly less than in newborn rabbits (24). Similar findings were reported in a study comparing the effects of isoproterenol in newborn puppies and adult dogs (25). Thus, results of physiologic experiments are consistent with our findings in isolated $S R$ vesicles.

Several investigators have reported that, in sheep, maturation of myocardial function is probably complete by 4 to 8 wk of age $(4,6,7)$. If maturation of SR function plays an important role in maturation of myocardial function, one would expect that maturation of SR function should occur also by 4 to $8 \mathrm{wk}$ of age. Certainly, the present experiments do not allow us to establish any direct correlation between physiologic and biochemical studies. However, our results do show that $\mathrm{SR} \mathrm{Ca}^{2+}$ transport is decreased in fetal and newborn hearts and gradually increases after birth, and this observation supports the hypothesis that alterations in function of the SR membrane contribute, at least in part, to developmental changes in myocardial function.

The complex mechanisms responsible for age-related differences in myocardial function are not fully known. However, 
regulation and control of intracellular $\mathrm{Ca}^{2+}$ concentration are of critical importance for maintaining normal myocardial function. It is generally accepted that the sarcolemma together with the $\mathrm{SR}$ regulates $\mathrm{Ca}^{2+}$ delivery to the myofibrils (23). The results of several recent studies suggest that the relative contribution to myoplasmic $\mathrm{Ca}^{2+}$ of these two membrane systems changes during development of the heart $(18,27,28)$. Ultrastructural studies have shown that the SR was underdeveloped in the immature myocardium $(19,27)$. Consistent with this was the observation that ryanodine, a plant alkaloid that selectively inhibits $\mathrm{Ca}^{2+}$ release from the SR $(21,22)$, produced a decreased negative inotropic response in immature hearts as compared to that in mature hearts (27). In addition, the inotropic response to paired electrical stimulation, which is thought to result from $\mathrm{Ca}^{2+}$ release from the SR, was greatly decreased in more immature hearts (18) again suggesting that the immature hearts were less dependent on $\mathrm{Ca}^{2+}$ release from the SR. The experiments described in this report, in which we have shown that SR $\mathrm{Ca}^{2+}$ transport is underdeveloped in the immature heart, support the hypothesis that the immature myocardium is relatively more dependent on trans-sarcolemmal $\mathrm{Ca}^{2+}$ influx than is the adult myocardium (18, $27,28)$.

In summary, the rate and maximal extent of $\mathrm{Ca}^{2+}$ uptake by $\mathrm{SR}$ vesicles were limited in fetal sheep by both decreased $\mathrm{Ca}^{2+}$ pump density and by inefficient coupling of $\mathrm{Ca}^{2+}$ transport to ATP hydrolysis. At birth, the $\mathrm{Ca}^{2+}$ pump density reached adult levels but the efficiency of the $\mathrm{Ca}^{2+}$ pump was decreased and remained so until after $8 \mathrm{wk}$ of age. We conclude that these agerelated changes in SR function are likely to contribute to developmental changes in myocardial function.

Acknowledgments. The author is grateful to Ronald Magness, Ph.D. and Mark Parrish, M.D. for critical review of the manuscript.

\section{REFERENCES}

1. Klopfenstein HS, Rudolph AM 1978 Post-natal changes in the circulation and responses to volume loading in sheep. Circ Res 42:839-845

2. Berman W, Musselman J 1979 Myocardial performance in the newborn lamb. Am J Physiol 237:H66-H70

3. Romero TE, Friedman WF 1979 Limited left ventricular response to volume overload in the neonatal period: a comparative study with the adult animal. Pediatr Res 13:910-935

4. Teitel DF, Sidi D, Chin T, Brett C, Heymann MA, Rudolph AM 1985 Developmental changes in myocardial contractile reserve in the lamb. Pediatr Res 19:948-955
5. Friedman WF 1972 The instrinsic physiologic properties of the developing heart. Prog Cardiovasc Dis 15:87-111

6. Minoura S, Gilbert RD 1987 Postnatal change of cardiac function in lambs: effects of ganglionic block and afterload. J Dev Physiol 9:123-135

7. Reimenschneider TA, Brenner RA, Mason DT 1981 Maturational changes in myocardial contractile state of newborn lambs. Pediatr Res 15:349-356

8. Tada M, Katz AM 1982 Phosphorylation of the sarcoplasmic reticulum and sarcolemma. Annu Rev Physiol 44:401-423

9. Mahony L, Jones LR 1986 Developmental changes in cardiac sarcoplasmic reticulum in sheep. $J$ Biol Chem 261:15257-15265

10. Lowry OH, Rosenbrough NJ, Farr AL, Randall RJ 1951 Protein measurement with Folin phenol reagent. J Biol Chem 193:265-275

11. Jones LR, Cala SE 1981 Biochemical evidence for functional heterogeneity of cardiac SR vesicles. J Biol Chem 256:1 1809-11818

12. Jones LR, Besch HR Jr 1984 Isolation of canine cardiac sarcolemmal vesicles. Methods Pharmacol 5:1-12

13. Tate CA, Chu A, McMillin-Wood J, VanWinkle WB, Entman ML 1981 Evidence for a calcium-sensitive factor which alters the alkaline $\mathrm{pH}$ sensitivity of sarcoplasmic reticulum transport. J Biol Chem 256:2934-2939

14. Amory A, Foury F, Goffeau A 1980 The purified plasma membrane ATPase of the yeast Schizosaccharomyces pombe forms a phosphorylated intermediate. J Biol Chem 255:9353-9357

15. Jones LR, Besch HR Jr, Watanabe AM 1978 Regulation of the calcium pump of cardiac sarcoplasmic reticulum. J Biol Chem 253:1643-1653

16. Zar JH 1974 Biostatistical Analysis. Prentice-Hall Englewood Cliffs, NJ

17. Sheldon CA, Friedman WF, Sybers HD 1976 Scanning electron microscopy of fetal and neonatal lamb cardiac cells. J Mol Cell Cardiol 8:853-862

18. Nakanishi T, Okuda H, Kamata K, Abe K, Sekiguchi M, Takao A 1987 Developmental of myocardial contractile system in the fetal rabbit. Pediatr Res 22:201-207

19. Pegg W, Michalak M 1987 Differentiation of sarcoplasmic reticulum during cardiac myogenesis. Am J Physiol 252:H22-H31

20. Nayler WG, Fassold E 1977 Calcium accumulation and ATPase activity of cardiac sarcoplasmic reticulum before and after birth. Cardiovas Res 11:231237

21. Marban E, Wier WG 1985 Ryanodine as a tool to determine the contributions of calcium entry and calcium release to the calcium transient and contraction of cardiac purkinje fibers. Circ Res 56:133-138

22. Sutko JL, Willerson JT 1980 Ryanodine alteration of the contractile state of rat ventricular myocardium. Comparison with dog, cat and rabbit ventricular tissues. Circ Res 46:332-343

23. Winegrad S 1979 In: Berne, RM, Sperelakis, N, Geiger, SR, (eds) Handbook of Physiology, Section 2, The Cardiovascular System, VI, The Heart. American Physiological Society, Bethesda, MD, pp 393-428

24. Okuda H, Nakanishi T, Nakazawa M, Takao A 1987 Effect of isoproterenol on myocardial mechanical function and cyclic AMP content in the fetal rabbit. J Mol Cell Cardiol 19:151-157

25. Park I-S, Michael H, Driscoll DJ 1982 Comparative response of the developing canine myocardium to inotropic agents. Am J Physiol 242:H13-H18

26. Nassar R, Reedy MC, Anderson PAW 1987 Developmental changes in the ultrastructure and sarcomere shortening of the isolated rabbit ventricular myocyte. Circ Res 61:465-483

27. Seguchi M, Harding JA, Jarmakani JM 1986 Developmental change in the function of the sacoplasmic reticulum. J Mol Cell Cardiol 18:189-195

28. Boucek RJ Jr, Citak M, Graham TP Jr, Artman M 1987 Effects of postnatal maturation on postrest potentiation in isolated rabbit atria. Pediatr Res 22:524-530 